University of Rhode Island

DigitalCommons@URI

Open Access Master's Theses

1983

\title{
THE EFFECT OF CHRONICALLY ADMINISTERED LSD ON THE SEROTONERGIC NERVOUS SYSTEM OF THE RAT
}

Bruce E. Fishman

University of Rhode Island

Follow this and additional works at: https://digitalcommons.uri.edu/theses

\section{Recommended Citation}

Fishman, Bruce E., "THE EFFECT OF CHRONICALLY ADMINISTERED LSD ON THE SEROTONERGIC NERVOUS SYSTEM OF THE RAT" (1983). Open Access Master's Theses. Paper 192.

https://digitalcommons.uri.edu/theses/192

This Thesis is brought to you for free and open access by DigitalCommons@URI. It has been accepted for inclusion in Open Access Master's Theses by an authorized administrator of DigitalCommons@URI. For more information, please contact digitalcommons@etal.uri.edu. 
THE EFFECT OF CHRONICALLY ADMINISTERED LSD

ON THE SEROTONERGIC NERVOUS SYSTEM OF THE RAT

by

Bruce E. Fishman

A thesis submitted in partial fulfillment

of the requirements for the degree of

Master of Science

in

Pharmacology and Toxicology

UNIVERSITY OF RHODE ISLAND

1983

7

$\because 9$ 


\section{MASTER OF SCIENCE DISSERTATION \\ $\mathrm{OF}$}

BRUCE E. FISHMAN

Approved :

Dissertation Committee

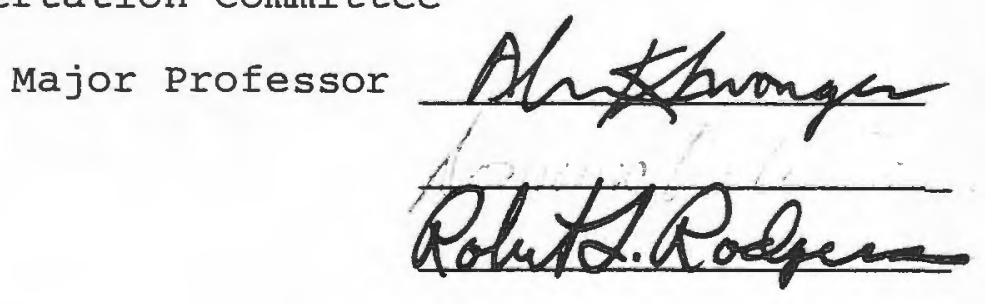

A. A. michel

UNIVERSITY OF RHODE ISLAND

1983 
Legitimate and illegitimate use of Iysergic acid diethylanide (LSD) increased dramatically in the 1960's. Since then, a number of studies have shown that LSD induces psychotic symptoms in the user, suggesting a possible correlation between exposure to LSD and certain psychoses. This hypothes is is supported by repeated observations that LSD inhibits 5-HT systems in the brain and that central 5-HT systems may be implicated in certain psychoses. The present study was designed to test the hypothesis that chronic administration of LSD to rats has an observable effect on 5-HT neuronal functioning in the brain. Rats were exposed to varying doses of LSD, and sacrificed 1 or 14 days after the last dose. Alteration in the 5-HT system was estimated by measurement of turnover of 5-HT, synaptosomal uptake of $(3 \mathrm{H}) 5-\mathrm{HT}$, and the extent of $(3 \mathrm{H}) 5-\mathrm{HT}$ and $(3 \mathrm{H})-$ spiroperidol binding. The results do not support the hypothesis. Chronic LSD administration had no effect on 5-HT turnover, uptake, or receptor binding. In light of these results, the possibility exists that LSD induces a psychotic effect in humans by other mechanisms. The possibility also exists that the effect in humans is not paralleled in rats. 


\section{ACKNOWLEDGEMENTS}

I would like to thank a number of people for their help in the completion of this endeavor. Thanks to Al Swonger for guidance and friendship, Gerry Ortolano for technical advice, and Bill McNaughton and Kathy Rancourt for valued technical assistance. I would also like to thank Bob Blitzer, Peter Burbelo, Ed McKenna, Dave Oisen; Bob Rodgers, Lisa Smith, and Dom Valent ino for being around. 
TABLE OF CONTENTS

$\underline{\text { Page }}$

ABSTRACT .............................

ACKNOWLEDGEMENTS ....................... . . i i i

TABLE OF CONTENTS ............................. iv

LIST OF TABLES ......................... . . . . v

LIST OF FIGURES ......................... . . vi

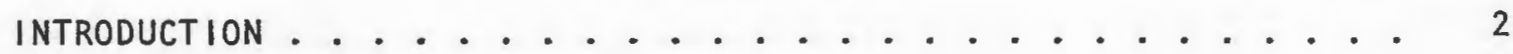

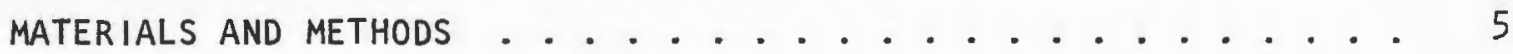

General Methods................... 8

Turnover Studies ... . . . . . . . . . . . 9

Synaptosomal Uptake Studies............... 10

Binding Assays .................. . . 11

RESULTS .............................. 13

Effect of LSD on 5-HT Turnover ............. 13

Effect of 5,6-Dihydroxytryptamine or LSD on (3H)5-HT Uptake . . 13

Effect of LSD on Affinity Constant and Maximum Number of

Binding Sites for ( $3 H$ ) 5-HT Receptors in Rat Cerebral

Cortex ......................... 14

Effect of LSD on Affinity Constant and Maximum Number of

Binding Sites for (3H)-Spiroperidol Receptors in Rat

Cerebral Cortex .................... 14

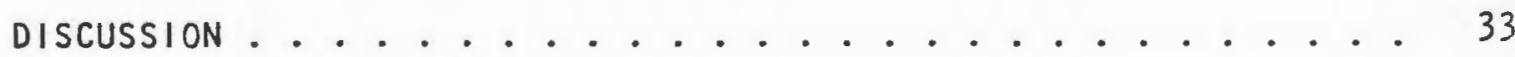

REFERENCES ............................ 37 


\section{LIST OF TABLES}

Page

TABLE 1: A Comparison of the Effect of 5,6-Dihydroxytryptamine or LSD on Synaptosomal Uptake of $(3 \mathrm{H}) 5-\mathrm{HT}$ in Rat Cerebral Cortex................. 16

TABLE 2: A Comparison of the Effect of LSD on the Affinity Constant and Maximum Number of Binding Sites for (3H) 5-HT in Rat Cerebral Cortex ...........

TABLE 3: A Comparison of the Effect of LSD on the Affinity Constant and Maximum Number of Binding Sites for (3H)-Spiroperidol in Rat Cerebral Cortex ....... 
FIGURE 1: A Comparison of Serotonin Turnover in the Cerebral Cortex of Rats after Acute LSD or Saline.......

FIGURE 2: A Comparison of Serotonin Turnover in the Cerebral Cortex of Rats after Seven Consecutive Days of Treatment with LSD or Saline Followed by Fourteen Days without Treatment Prior to Sacrifice . . . . .

FIGURE 3: A Comparison of Serotonin Turnover in the Cerebral Cortex of Rats after Fourteen Consecutive Days of Treatment with LSD or Saline Followed by Fourteen Days without Treatment Prior to Sacrifice . . . . 25

FIGURE 4: A Comparison of Serotonin Turnover in the Cerebral Cortex of Rats after Fourteen Consecutive Days of Treatment with LSD or Saline Followed by One Day Without Treatment Prior to Sacrifice........

FIGURE 5: A Comparison of Serotonin Turnover in the Cerebral Cortex of Rats after Fourteen Consecutive Days of Treatment with LSD or Saline Followed by Fourteen Days without Treatment Prior to Sacrifice ......

FIGURE 6: Representative Scatchard Plot Analysis of the Data of Table 3, Experiment 2............. 
THE EFFECT OF CHRONICALLY ADMINISTERED LSD

ON THE SEROTONERGIC NERVOUS SYSTEM OF THE RAT 
Page 2

\section{INTRODUCTION}

Since the accidental discovery by Hofmann of the intense hallucinatory effect of d-lysergic acid diethylamide (LSD) in 1943, this drug has been among the most noteworthy in modern times. As one of the most potent hallucinogens known to man, LSD has been the basis of an immense body of published literature. LSD has been employed for a variety of legitimate purposes, including use by psychiatrists for the treatment of patients with neurotic disorders (Chandler and Hartman, 1960; Ling and Buckman, 1963; and Levine and Ludwig, 1964).

The subjective effects of LSD have been characterized as consisting of impairments of sensory perception and thought processes. The term "illucinogenic" has been coined for use in association with LSD, since the drug is described as altering reality rather than producing hallucination (Sankar, 1975) in the mind of the user.

Illicit use of LSD has become popular since the drug appeared in the 1960's. However, numerous accounts have been recorded by psychiatrists describing patients who have experienced psychotic episodes persisting or beginning weeks or even months after their last exposure to the drug. For example, Elkes (1963) described delayed reactions to LSD such as changes in mood, perceptual distortions, depersonalization, and confusion. Other discussions of psychoses presumably induced by LSD include Cohen (1960), Fink, Simeon, Hawe, and Itil (1966), and Ungerleider, Fisher and Fuller (1966).

The psychotic symptoms have been characterized in the DSM-111, 1981, as comprising two syndromes. These are an organic delusional syndrome 
and an organic affective syndrome. The delusional syndrome consists of delusions, or the belief in something not real, while the patient is in a normal state of consciousness. The organic affective syndrome consists of mood instability. Both of these disorders are associated with hallucinations, paranoia and personality disintegration. Another psychiatric disorder arising from the use of LSD is the flashback phenomenon. Flashbacks are repetitions of hallucinatory perceptions occurring weeks or months after the effect of the drug has worn off. This phenomenon is described by Welpton (1968) and Horowitz (1969).

The biochemical basis of these LSD-induced psychotic effects has been the object of a number of scientific inquiries. It has been shown that intravenously administered LSD has a half-life in the human body of approximately three hours (Aghajanian and Bing, 1964). This suggests a rapid el imination of the drug. This, in association with the psychiatric data, suggests that LSD may be causing some effect that persists after its removal.

A large amount of research has been carried out in an attempt to elucidate the mechanism of action of LSD in the central nervous system. Rosencrans et al (1967) showed that acute exposure to LSD caused rat brain 5-HT to increase and level off after 90 minutes. Aghajanian et al (1972), using microiontophoretic methods, administered LSD to the midbrain raphe nuclei. This caused a potent inhibition of the rhythmic firing of the 5-HT neuronal cell bodies residing there. Aghajanian et al (1982) measured intracellular recordings from the rat raphe which demonstrated inhibition of 5-HT neuronal firing by LSD. It has been proposed by some researchers (Diaz and Huttenan, 1972; Peters 1973) that this 
profound effect of LSD on 5-HT neurons could be the mechanism of LSDinduced psychotic manifestations. Weight is added to this hypothesis due to the extensive study of biogenic amines including 5-HT in schizophrenia and related psychotic disorders. The biogenic amine hypothesis int imately relates 5-HT with psychosis (Baldessarini et al, 1972; Garver and Davis, 1979).

Researchers have attempted to examine the effects of LSD on 5-HT turnover with conflicting results. Diaz and Huttenan (1972) administered $20 \mathrm{ug} / \mathrm{kg}$ LSD to rats orally on a daily basis for one month. They reported an increase in 5-HT in the whole brain preparation. Other research (Peters, 1973; Peters, 1976) reported a decrease in 5-HT turnover in the midbrain after administration of $20 \mathrm{ug} / \mathrm{kg} /$ day LSD for various periods of time. Peters (1974) reported an increase in 5-HT turnover when $100 \mathrm{ug} / \mathrm{kg} /$ day was administered.

The doses and time periods chosen for the experiments carried out in our study were decided upon based on this previously reported data. Treatment conditions consisting of similar time periods but much larger doses of LSD (10 times the $E D_{50}$ ) were utilized in order to insure the occurrence of an effect if one was to be observed. 
MATERIALS AND METHODS

In recent years, a variety of biochemical methods have been developed with which researchers can study the activity of neurons and neurotransmitters. Three biochemical parameters which can be utilized to determine the integrity of a neurotransmitter system are neurotransmitter turnover, uptake of radiolabeled neurotransmitter, and the binding of radioligands to neurotransmitter receptors.

Turnover of a neurotransmitter refers to the renewal of the substance: Certain assumptions should be met in order to measure the turnover of 5-HT in the brain (Neff et al, 1968). These assumptions can be summarized as follows: (1) 5-HT enters the system by synthes is and is lost by metabolism, (2) a steady state exists where the rate of formation of 5-HT equals its degradation, (3) the turnover rate of $5-H T$ remains consistent but not necessarily equal during experimentation, and (4) no distinction is made between newly synthesized and old molecules of 5-HT. Tozer et al (1966) and Neff and Tozer (1968) have evaluated the measurement of 5-HT turnover after pargyline administration. The levels of 5-HT continue to rise after inhibition of MAO until the rising levels of 5-HT block the process (Millard et al, 1972; Baumann and Valdmeier, 1981). This phenomenon has been called "end product inhibition".

The method of measuring high-affinity synaptosomal uptake of radiolabeled neurotransmitters began with the development of methods which allowed intact nerve endings to be pinched off and separated (Gray and Whittaker, 1962). It was later shown that these high-affinity uptake mechanisms were sodium-dependent, ouabain-sensitive, and saturable (Bogdanski et al, 1968). Kuhar et al (1972) demonstrated that the uptake 
of (3H)5-HT in rat forebrain was carried out by 5-HT neurons. By lesioning the midbrain raphe, 5-HT uptake was selectively reduced. The parameters of this experimental methodology were worked out by Shaskan and Snyder (1970). A general description of the methodology was published by Kuhar (1973). More recently, high-affinity synaptosomal uptake has been used to measure long-term effects of methylamphetamine on 5-HT neurons in rat brain (Ricaurte et al, 1980).

The most recently developed methodology utilized to detect alterations in neurotransmitter systems is radioligand-receptor binding technique. In rat brain preparations, (3H) 5-HT has been shown to bind in a saturable fashion and with regional variations consistent with the theorized location of the 5-HT postsyraptic receptor (Bennet and Snyder, 1975). At the same time, other researchers came to similar conclusions using membrane preparations (Fillion et al, 1975), These results have since been reproduced with a reasonable amount of consistency (Fillion et al, 1977; Peroutka et al, 1979). Recent experimentation has also advanced the hypothesis that there are subgroups of 5-HT receptors with differing binding capabilities for various radioligands.

In the rat cerebral cortex, two main subgroups of 5-HT receptors have been hypothesized to exist. One group of receptors has a high affinity for (3H)5-HT, while the other group of receptors has a high affinity for 3H-spiropridol and other 5-HT antagonists (Leysen and Laduron, 1977; Quik et al, 1978). Spiroperidol is a butyrophenone neuroleptic drug originally developed for elinical use but judged to be unsuitable due to severe side effects. In the cortex, (3H)5-HT and (3H)spiroperidol have been shown to be displaceable by LSD, and (3H)-LSD has 
been shown to bind to the sites of both radioligands (Creese and Snyder, 1978; Peroutka and Snyder, 1979; and Seeman et al, 1980). Both 5-HT and spiroperidol have been shown to displace (3H)-LSD from cortical binding sites (Peroutka and Snyder, 1979). The high-affinity (3H)-spiroperidol binding site has been hypothesized to be serotonergic due to the ability of 5-HT antagonists such as LSD, cinanserin, and mianserin to displace it from cortical binding sites, where it is most abundant (Peroutka and Snyder, 1981). This evidence combined suggests that 5-HT and spiroperidol bind to separate subgroups of $5-\mathrm{HT}$ receptors in the cerebral cortex and that LSD binds to both. Disagreement does exist, however, to the hypothes is that (3H)-spiroperidol labels a 5-HT receptor (Middlemiss et al, 1980). It is interesting to note that this is due to conflicting results, and not theoretical argument.

Although lesions of the midbrain raphe have been shown not to cause adaptive changes in either of the two subgroups of receptors described above (Blackshear et al, 1981), chronic administration of tricyclic antidepressants has been shown to produce a decrease in the number of cerebral cortex 5-HT receptor binding sites (Segawa et al, 1979; Kel lar et al, 1981; and Maggi et al, 1981). Alterations in (3H)-spiroperidol binding have been found in rat striatum after chronic methylamphetamine administration (Akiyama et al, 1982).

The purpose of this project is to gain a deeper understanding of the mechanism by which LSD acts on the 5-HT system in the cerebral cortex and the rest of the brain. We have attempted to identify and characterize adaptive changes in the 5-HT system after chronic administration of high 
doses of LSD. It is hypothesized that the LSD-induced psychoses diagnosed by psychiatrists can be linked to altered functioning of the 5-HT system. If this is so, then demonstration of induced biochemical adaption will greatly enhance the understanding of the causes and effects of psychoses.

General Methods

All rats used in these experiments were male Long-Evans (Charles River Breeding Laboratories, Waltham, Massachusetts) weighing between 200-250 grams at time of sacrifice. All treatments of LSD to rats were administered via the intraperitoneal route. All rats were guillotined without anesthesia. Whole brains were rapidly removed over ice. The brains were dissected based on descriptions by Glowinski and Iversen (1966) with modifications. The cerebral hemispheres were separated with one stroke of a spatula. The cortices were peeled back and stripped from the underlying tissue. Cortices used in turnover studies were assayed immediately after sacrifice. Tissue used in uptake and binding studies was stored at $-70^{\circ} \mathrm{C}$ until assay (less than four weeks).

Treatments for administration of LSD consisted of the same pair of conditions for all three methods utilized. Rats were treated with 1 $\mathrm{mg} / \mathrm{kg} /$ day LSD for 14 consecutive days followed by one drug-free day prior to sacrifice, or they were treated with $1 \mathrm{mg} / \mathrm{kg} /$ day LSD for 14 consecutive days followed by 14 drug-free days prior to sacrifice. In the turnover studies, additional experiments were conducted using varying conditions. These were an acute study of $100 \mathrm{ug} / \mathrm{kg}$ LSD at six hours prior to sacrifice; seven consecutive days of treatment with $1 \mathrm{mg} / \mathrm{kg} / \mathrm{day}$ LSD followed by 14 days without treatment prior to sacrifice, and 14 consecutive 
days of treatment with $0.5 \mathrm{mg} / \mathrm{kg} /$ day LSD followed by $14 \mathrm{drug}-\mathrm{free}$ days prior to sacrifice.

In the turnover studies, rats were treated with the monamine oxidase inhibitor, pargyline, $75 \mathrm{mg} / \mathrm{kg}$ i.p. at 0,2 , or 4 hours prior to sacrifice. In the uptake studies, one group of rats was given 75 ug of 5,6dihydroxytryptamine, a selective 5-HT neurotoxin, two weeks prior to sacrifice. The 5,6-DHT was administered intracerebroventricularly as described by Noble et al (1967) with a few differences. The stereotaxic apparatus used in this study was provided by David Kopf Company, Tujunga, California.

Turnover Studies

The method of Curzon and Green (1970) was used to measure 5-HT fluorescence. The determination of levels of 5-HT after pargyline was accomplished by measuring the fluorescence of 5-HT bound to the fluorescent marker compound, ortho-phthalaldehyde (OPT). The method was slightly modified by Ciarlone (1976). Tissue was first weighed, then homogenized in 10 volumes of acidified n-butanol using a polytron homogenizer at speed 4 for 30 seconds. Internal standards were used. These were added in $0.3 \mathrm{ml}$ al iquots of $0.1 \mathrm{~N} \mathrm{HCl}$ to $3 \mathrm{ml}$ of $\mathrm{n}$-butanol. The samples were dissolved in a similar volume of $\mathrm{HCl}$. These were centrifuged at $1,000 \times$ $\mathrm{g}$ for five minutes. Two and one-half $\mathrm{ml}$ of the supernatant was aspirated and added to tubes containing $1.6 \mathrm{ml}$ of $0.1 \mathrm{~N} \mathrm{HCl}$ and $5 \mathrm{ml}$ of $\mathrm{n}$-heptane. These were vigorously shaken for five minutes. The organic phase was then aspirated. A $0.2 \mathrm{ml}$ aliquot of the aqueous phase was removed for analysis. Each sample was added to $1.2 \mathrm{ml}$ of $4 \mathrm{mg} \%$ OPT and placed in a 
bath of boiling water for 10 minutes. The samples were allowed to cool after removal. Fluorescence was read using an Aminco-Bowman spectrophoto fluorometer at 355 excitation and 470 emission. Values were expressed in ug 5-HT/gram tissue wet weight.

Synaptosomal Uptake Studies

The assay procedure was modified from the method of Coyle and Snyder (1979). The frozen tissue was weighed and deposited in 10 volumes of $0.32 \mathrm{M}$ sucrose. This was then homogenized using a motor-driven teflon glass pestle with a clearance of $0.03 \mathrm{~cm}$, at about $1,000 \mathrm{rpm}$. Ten upand-down strokes were used in homogenization. The homogenates were centrifuged at $4^{\circ} \mathrm{C}$ at $700 \times \mathrm{g}$ for 10 minutes. The pellet was then discarded. The synaptosomal homogenate was divided into six aliquots of $0.2 \mathrm{ml}$ each. These were evenly divided among $0^{\circ} \mathrm{C}$ and $37^{\circ} \mathrm{C}$ incubations. The $0.2 \mathrm{ml}$ synaptosomal homogenates were each added to $0.8 \mathrm{ml}$ of incubation medium. The medium contained: $\mathrm{NaCl}(118.5 \mathrm{mM}), \mathrm{KCl}(4.8 \mathrm{mM}), \mathrm{KH}_{2} \mathrm{PO}_{4}(1.2 \mathrm{mM})$, $\mathrm{MgSO}_{4}(1.2 \mathrm{mM}), \mathrm{NaHCO}_{3}(24.8 \mathrm{mM})$, EDTA $(0.13 \mathrm{mM})$, pargyline $\left(10^{-5} \mathrm{M}\right)$, ascorbate $(0.2 \mathrm{mg} / \mathrm{ml}), \mathrm{d}-\mathrm{glucose}(1 \mathrm{mg} / \mathrm{ml})$, and $(3 \mathrm{H}) 5-\mathrm{HT}\left(10^{-8} \mathrm{M}\right)(20 \mathrm{Ci} /$ mM, New England Nuclear Corporation, Boston, Massachusetts). The mixture was gassed for 15 minutes prior to use with $95 \% \mathrm{O}_{2}: 5 \% \mathrm{CO}_{2}$. The $37^{\circ} \mathrm{C}$ samples were incubated for six minutes, after which they were replaced in an ice bath with the $0^{\circ} \mathrm{C}$ samples. All tubes were centrifuged at $1,000 \times \mathrm{g}$ for 60 minutes. The supernatant was aspirated and discarded. The pellet was vortexed with $1 \mathrm{ml}$ absolute ethanol and immediately rinsed with another $1 \mathrm{ml}$ of absolute ethanol. These were added to scintillation vials with $10 \mathrm{ml}$ Econofluor (New England Nuclear Corporation). Protein measurements 
were carried out using the method of Lowry et al (1951). Specific synaptosomal uptake of (3H)5-HT was calculated by subtracting the mean value of the $0^{\circ} \mathrm{C}$ incubation samples from those obtained from the $37^{\circ} \mathrm{C}$ incubations. Radioactivity was measured using a Packard Tri-Carb model 3335 liquid scintillation spectrometer. Uptake was expressed as PM (3H)5-HT/ mg protein/six minutes.

\section{Binding Assays}

The tissue preparation and assay procedure was a modification of the method of Peroutka and Snyder (1979). The frozen tissue was weighed and placed in 10 volumes of ice-cold $0.32 \mathrm{M}$ sucrose. This was homogenized using a motor-driven teflon-glass pestle. The speed was 1,000 rpm and 10 up-and-down strokes were used. The resulting homogenate was centrifuged at $700 \times \mathrm{g}$ for 10 minutes. The pellet was discarded. The supernatant was removed and centrifuged at $50,000 \times \mathrm{g}$ for 10 minutes. The resulting pellet was separated from the supernatant and incubated in 10 volumes of $50 \mathrm{mM}$ Tris buffer $\left(\mathrm{pH} 7.4\right.$ at $\left.25^{\circ} \mathrm{C}\right)$ after resuspension. After this incubation, the preparation was recentrifuged at $50,000 \times \mathrm{g}$ for 10 minutes. The supernatant was again discarded and the pellet was resuspended in 10 volumes of Tris buffer $\left(\mathrm{pH} 7.4\right.$ at $25^{\circ} \mathrm{C}$ ) with $1 \mathrm{mg} / \mathrm{ml}$ abscorbate and $10^{-5} \mathrm{M}$ pargyline. This preparation was incubated at $37^{\circ} \mathrm{C}$ for 10 minutes and then frozen at $-70^{\circ} \mathrm{C}$ until use (not more than four weeks).

For assay, the tissue preparation was diluted to 80 volumes. Incubation tubes received $0.8 \mathrm{ml}$ of tissue, $0.1 \mathrm{ml}$ of $(3 \mathrm{H})-1$ igand solution, and $0.1 \mathrm{ml}$ of displacer or buffer. Final tissue concentration was 10 
$\mathrm{mg} / \mathrm{ml}$. The final concentrations of the $(3 \mathrm{H})-1$ igands were $0.2 \mathrm{nM}$ for spiroperidol and $2.0 \mathrm{nM}$ for $5-\mathrm{HT}$. The tubes were incubated at $37^{\circ} \mathrm{C}$ for

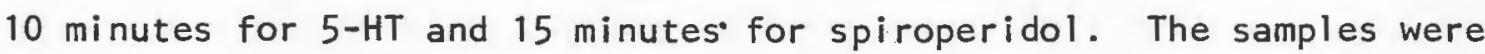
cooled in an ice bath for 15 minutes after incubation. They were then rapidly filtered through Whatman GF/B filters with three $5 \mathrm{ml}$ rinses of ice-cold $50 \mathrm{mM}$ Tris buffer $\left(\mathrm{pH} 7.4\right.$ at $\left.25^{\circ} \mathrm{C}\right)$. The filters were heated until dried and added to scintillation vials with $10 \mathrm{ml}$ Econofluor. The samples were allowed to equilibrate overnight and counted the following day in a Packard Tri-Carb model 3335 liquid scintillation spectrometer. Specific binding of (3H)5-HT was defined to be the excess over blank in the presence of $10^{-5} \mathrm{M}$ unlabeled 5-HT and that of (3H)-spiroperidol in the presence of $10^{-6} \mathrm{M}$ unlabeled spiroperidol. (3H) $5-\mathrm{HT}(26.3 \mathrm{Ci} / \mathrm{mM})$ and $(3 \mathrm{H})$-spiroperidol $(23.8 \mathrm{Ci} / \mathrm{mM})$ were obtained from New England Nuclear Corporation, Boston, Massachusetts. Other reagents were obtained from Sigma Chemical Company (St. Louis, Missouri).

\section{Statistics}

For turnover studies, differences in results were considered insignificant if the standard errors of the means overlapped. In uptake studies, the students' $t$-test was used to determine if differences between the drug-treated and control conditions existed. In binding studies, linear regression analysis was utilized to determine the best fit on a straight line for the six points of the Scatchard plot. The students' t-test was used to determine whether or not the mean kd (dissociation constant, measured as the - inverse of the slope of the line) or mean Bmax (maximum number of binding sites, measured as the " $x$ " intercept of the line) were different in treated and control groups. 


\section{RESULTS}

Effect of LSD on 5-HT Turnover

The effect of an acute dose of $100 \mathrm{ug} / \mathrm{kg}$ LSD is shown in figure 1. The level of $5-\mathrm{HT}$ at the time of sacrifice was increased from $0.7 \mathrm{ug} / \mathrm{g}$ to $0.9 \mathrm{ug} / \mathrm{g}$. Also, turnover was inhibited at all time points. Figure 2 shows the turnover curve for treatment with $1 \mathrm{mg} / \mathrm{kg} /$ day LSD for seven consecutive days followed by a 14-day period without treatment. Figure 3 denotes the effect of $0.5 \mathrm{mg} / \mathrm{kg} /$ day LSD administered daily for 14 consecutive days followed by 14 drug-free days. The two-hour point of figure 3 was found to show a difference between treated and control. Figure 4 shows the effect of $1 \mathrm{mg} / \mathrm{kg} /$ day LSD for 14 consecutive days followed by one day without treatment prior to sacrifice. Figure 5 shows the effect of $1 \mathrm{mg} / \mathrm{kg} /$ day LSD for 14 consecutive days followed by 14 days without treatment prior to sacrifice.

Effect of 5,6-Dihydroxytryptamine or LSD on (3H) 5-HT Uptake

Intracerebral injection of 75 ug of 5,6-DHT dissolved in physiological saline was shown to reduce (3H)5-HT uptake in rat cerebral cortex 14 days after administration. Uptake was diminished by $29 \%$ from shamtreated controls. The control value was $2.18 \pm 0.14$, while the $5,6-$ DHT treated value was $1.55 \pm 0.19$ (Table 1 ). Administration of $1 \mathrm{mg} / \mathrm{kg} / \mathrm{day}$ LSD for 14 consecutive days followed by 1 or 14 days without treatment prior to sacrifice caused no significant change between drug-treated or control (3H)5-HT uptake in the rat cerebral cortex (Table 1). Data is expressed as picomoles $(3 \mathrm{H}) 5-\mathrm{HT} / \mathrm{mg}$ protein/six minutes. 
Page 14

Effect of LSD on Affinity Constant and Maximum Number of Binding Sites for (3H) 5-HT Receptors in Rat Cerebral Cortex

Table 2 shows the effects on rats of $1 \mathrm{mg} / \mathrm{kg} /$ day LSD for 14 consecutive days followed by one drug-free day prior to sacrifice (experiment 1). The $\mathrm{Kd}$ value for control rats was $6.76 \pm 0.36 \mathrm{mM}$, while for LSDtreated rats it was $6.92+0.60 \mathrm{nM}$. The $B$ max for the controls was 7.93 \pm 0.42 , while for the LSD-treated group it was $8.58 \pm 0.47 \mathrm{pM} / \mathrm{g}$. Experiment 2 shows the effect of $1 \mathrm{mg} / \mathrm{kg} /$ day LSD for 14 consecutive days followed by 14 days of no treatment prior to sacrifice. The Kd value for control was $6.81 \pm 0.66 \mathrm{nM}$, while for the LSD-treated group it was 6.32 $\pm 0.45 \mathrm{nM}$. The Bmax for the control group was $7.90 \pm 0.39 \mathrm{pM} / \mathrm{g}$, while for the LSD-treated group it was $7.37 \pm 0.49 \mathrm{pM} / \mathrm{g}$.

Effect of LSD on Affinity Constant and Maximum Number of Binding Sites for (3H)-Spiroperidol Receptors in Rat Cerebral Cortex

Table 3 shows the effects of $1 \mathrm{mg} / \mathrm{kg} /$ day LSD for 14 consecutive days with one day without treatment prior to sacrifice (experiment 1). The Kd value for control rats was $1.09+0.046$, while for the LSD-treated group it was $1.12 \pm 0.150$. The Bmax for the control group was $4.15 \pm$ 0.26 , while for the LSD-treated group it was $3.79 \pm 0.48$. Experiment 2 shows the effect of $1 \mathrm{mg} / \mathrm{kg} /$ day LSD for 14 consecutive days followed by 14 days of no treatment prior to sacrifice. The Kd value for the control group was $1.16 \pm 0.09$, while for the LSD-treated group it was 1.10 \pm 0.02 . The Bmax for the control group was $4.54 \pm 0.54$, while for the LSD-treated group it was $4.34 \pm 0.43$. Affinity constant data was expressed in nanomoles (3H)-ligand and binding site data was expressed 
in picomoles $(3 \mathrm{H})-1$ igand/gram tissue wet weight. Figure 6 shows a typical Scatchard plot based on the data of Table 2, experiment 2. 
Table 1. A Comparison of the Effect of 5,6-Dihydroxytryptamine or LSD on Synaptosomal Uptake of (3H)5-HT in Rat Cerebral Cortex

\begin{tabular}{|c|c|c|}
\hline & $\begin{array}{c}\mathrm{pM}(3 \mathrm{H}) 5-\mathrm{HT} / \mathrm{mg} \\
\text { Protein/6 Min } \pm \text { SEM }\end{array}$ & $\mathrm{n}$ \\
\hline \multicolumn{3}{|l|}{ Experiment 1: } \\
\hline Control & $2.18 \pm 0.14$ & 3 \\
\hline 5,6-DHT, $75 \mathrm{ug}$ & $1.55 \pm 0.19$ & $3 *$ \\
\hline \multicolumn{3}{|l|}{ Experiment 2: } \\
\hline Control & $2.49 \pm 0.19$ & 3 \\
\hline LSD, I mg/kg/day, & $2.26 \pm 0.25$ & 3 \\
\hline 14 drug-free da & & \\
\hline \multicolumn{3}{|l|}{ Experiment 3 : } \\
\hline Control & $2.25 \pm 0.34$ & 3 \\
\hline LSD, $1 \mathrm{mg} / \mathrm{kg} / \mathrm{day}$, & $1.92 \pm 0.40$ & 3 \\
\hline 14 drug-free day & & \\
\hline
\end{tabular}

* Represents statistical significance 
Table 2. A Comparison of the Effect of LSD on the Affinity Constant and Maximum Number of Binding Sites for (3H)5-HT in Rat Cerebral Cortex

Kd $(n M) \pm S E M \quad B \max (p M / g) \pm S E M \quad \underline{n}$

Experiment 1:

$\begin{array}{llll}\text { Control } & 6.76 \pm 0.36 & 7.93 \pm 0.42 & 3 \\ \text { LSD, } 1 \mathrm{mg} / \mathrm{kg} / \text { day, } & 6.92 \pm 0.60 & 8.58 \pm 0.47 & 3 \\ 1 \text { drug-free day } & & & \end{array}$

Experiment 2:

$\begin{array}{llll}\text { Control } & 6.81 \pm 0.66 & 7.90 \pm 0.39 & 5 \\ \text { LSD, } 1 \mathrm{mg} / \mathrm{kg} / \text { day, } & 6.32 \pm 0.45 & 7.37 \pm 0.49 & 5\end{array}$

14 drug-free days 
Table 3. A comparison of the Effect of LSD on the Affinity Constant and Maximum Number of Binding Sites for (3H)-Spiroperidol in Rat Cerebral Cortex

$$
\underline{K d(n M) \pm S E M} \quad \underline{B m a x}(\mathrm{pM} / \mathrm{g}) \pm S E M \quad \underline{\mathrm{n}}
$$

Experiment 1:

Control

LSD, $1 \mathrm{mg} / \mathrm{kg} / \mathrm{day}$,

1 drug-free day

\section{Experiment 2:}

Control

LSD, $1 \mathrm{mg} / \mathrm{kg} / \mathrm{day}$, 14 drug-free days

$$
1.09 \pm .046
$$

$4.15 \pm 0.26$

3

$1.12 \pm .150$

$3.79 \pm 0.48$

3
$4.52 \pm 0.54$

3

$4.34 \pm 0.43$

3 


\section{LEGENDS TO FIGURES}

Figure 1: Rats were administered $100 \mathrm{ug} / \mathrm{kg}$ LSD i.p. six hours prior to sacrifice. Rats were sacrificed at 0,2 , and 4 hours after treatment with $75 \mathrm{mg} / \mathrm{kg}$ pargyline. All data points represent the mean of a minimum of four determinations.

Figure 2: Rats were administered LSD (1 mg/kg/day for seven days), followed by 14 days without treatment prior to sacrifice. Rats were administered $75 \mathrm{mg} / \mathrm{kg}$ pargyline at 0,2 , and 4 hours prior to sacrifice. All data points represent the mean of a minimum of four determinations.

Figure 3: Rats were administered LSD $(0.5 \mathrm{mg} / \mathrm{kg} /$ day for 14 days), followed by 14 days without treatment prior to sacrifice. Rats were administered pargyline, $75 \mathrm{mg} / \mathrm{kg} \mathrm{i.p.,} \mathrm{at} 0,2$, and 4 hours prior to sacrifice. All data points represent the mean of a minimum of four determinations.

Figure 4: Rats were administered LSD $(1 \mathrm{mg} / \mathrm{kg} /$ day for 14 days), followed by one day without treatment prior to sacrifice. Rats were administered pargyline, $75 \mathrm{mg} / \mathrm{kg}$ i.p., at 0,2 , and 4 hours prior to sacrifice. All data points represent the mean of a minimum of four determinations. 
Figure 5: Rats were administered LSD (1 mg/kg/day for 14 days), followed by 14 days without treatment prior to sacrifice. Rats were administered $75 \mathrm{mg} / \mathrm{kg}$ pargyline i.p. at 0,2 , and 4 hours prior to sacrifice. All data points represent the mean of a minimum of six determinations.

Figure 6: Data is based on the results of three experiments. $X$-axis - Picomoles (3H)-spiroperidol/g tissue wet weight. Y-axis - Picomoles (3H)-spiroperidol/g tissue/nM (3H)-spiroperidol. Correlation coefficient -0.97 . 
Figure 1. A COMPARISON OF SEROTONIN TURNOVER IN THE CEREBRAL CORTEX OF RATS AFTER ACUTE LSD OR SALINE 
Page 22

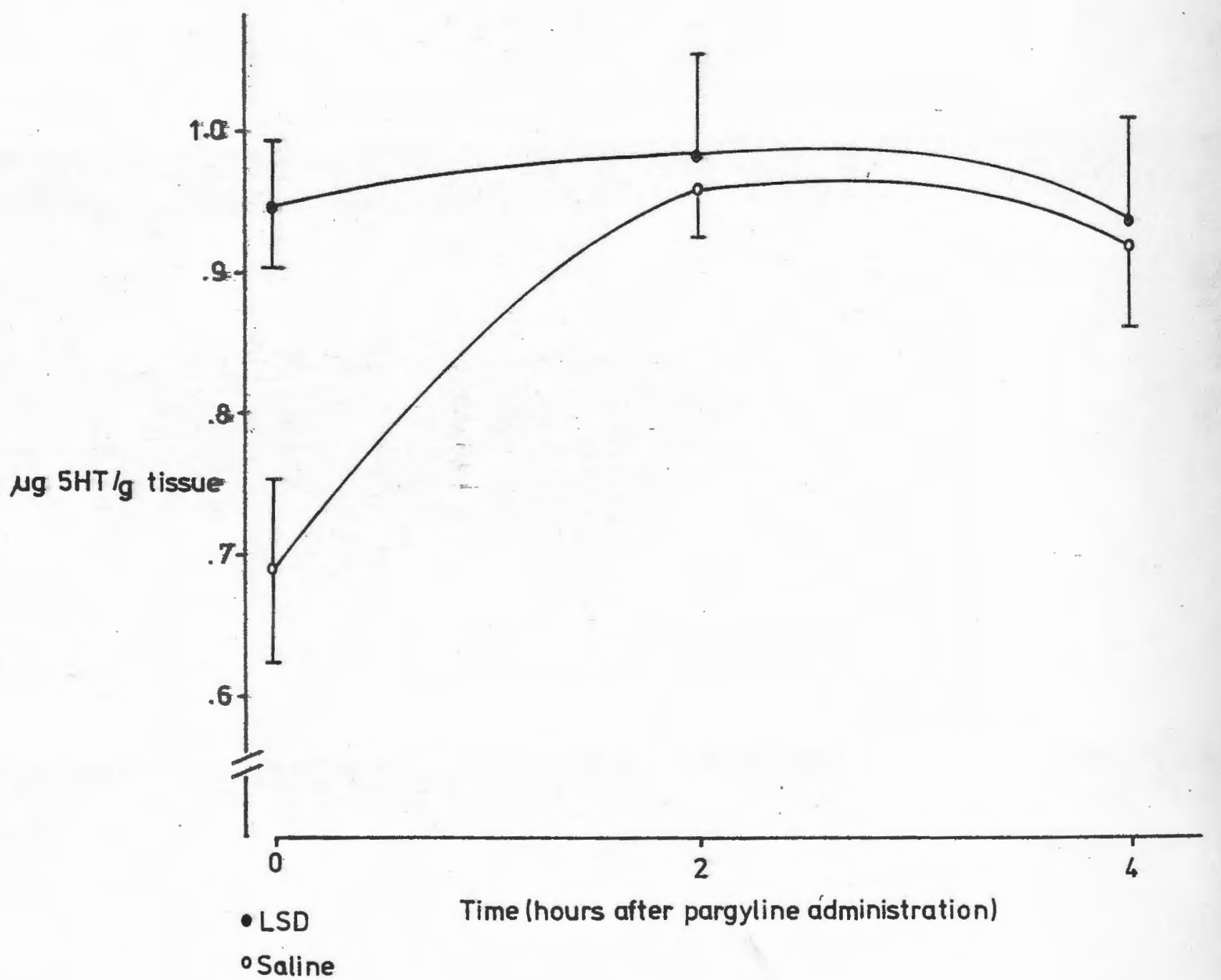


Page 23

Figure 2. A COMPARISON OF SEROTONIN TURNOVER IN THE CEREBRAL CORTEX OF RATS AFTER SEVEN CONSECUTIVE DAYS OF TREATMENT WITH LSD OR SALINE FOLLOWED BY FOURTEEN DAYS WITHOUT TREATMENT PRIOR TO SACRIFICE 
Page 24

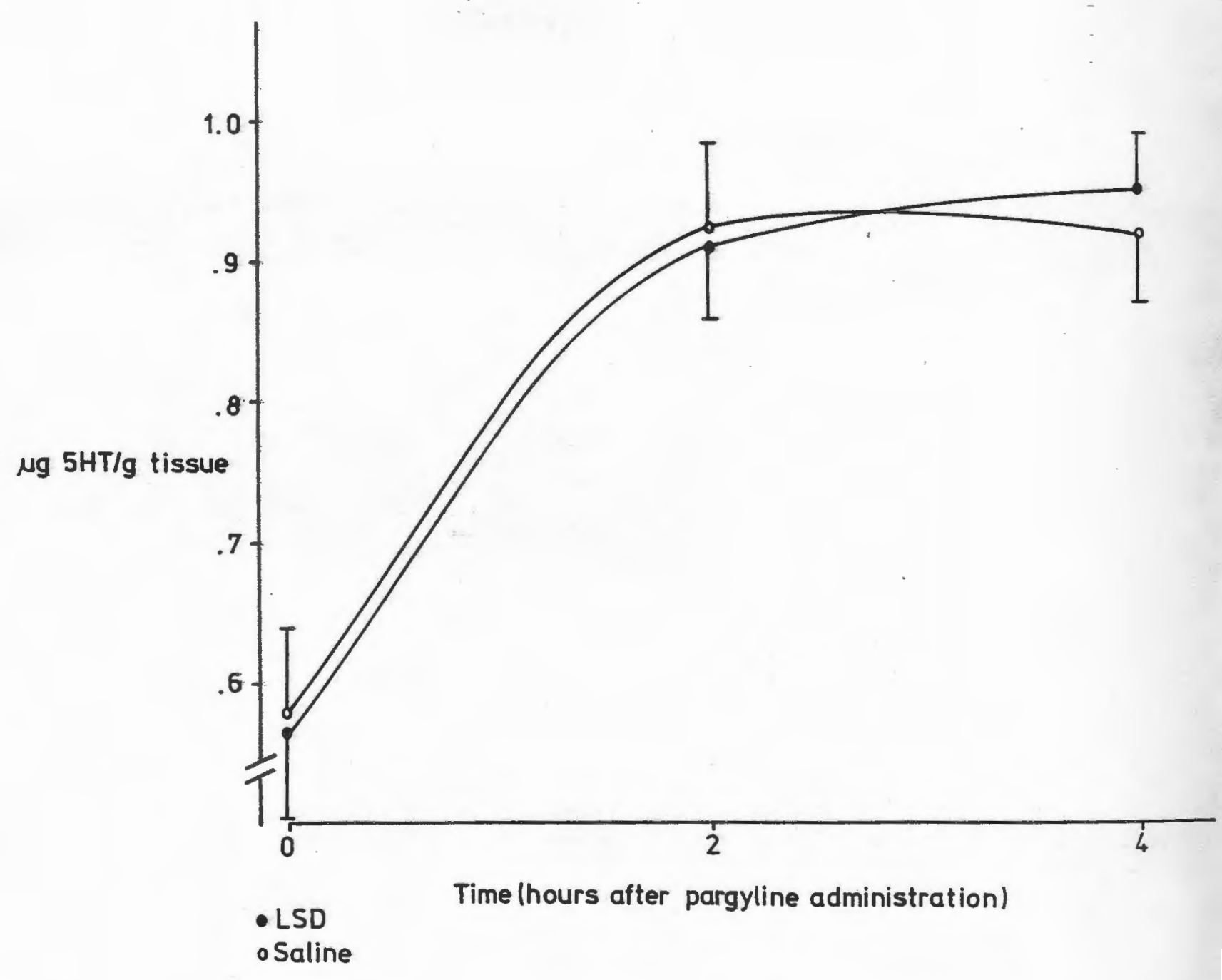


Figure 3. A COMPARISON OF SEROTONIN TURNOVER IN THE CEREBRAL CORTEX OF RATS AFTER FOURTEEN CONSECUTIVE DAYS OF TREATMENT WITH LSD OR SALINE FOLLOWED BY FOURTEEN DAYS WITHOUT TREATMENT PRIOR TO SACRIFICE. 


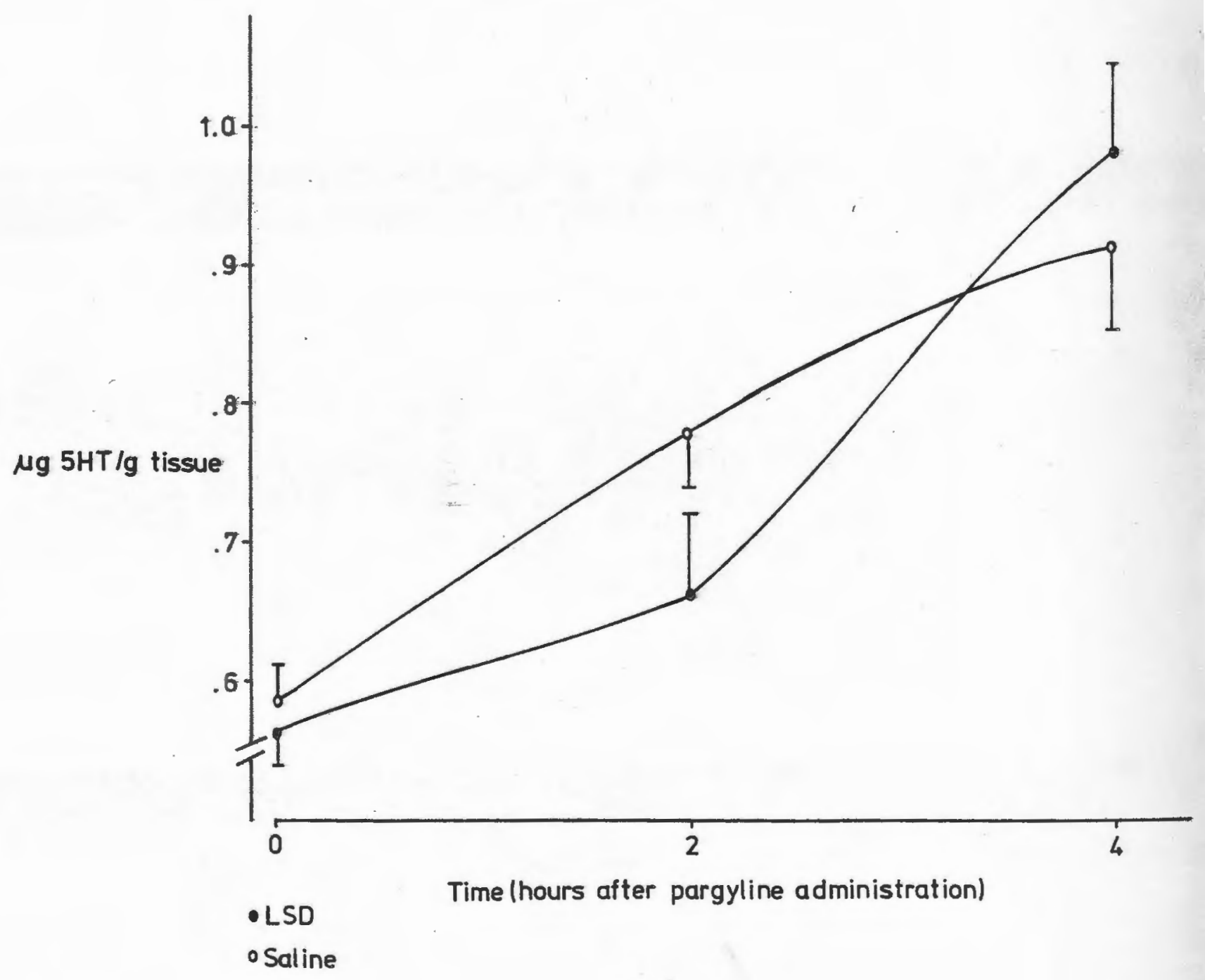


Figure 4. A COMPARISON OF SEROTONIN TURNOVER IN THE CEREBRAL CORTEX OF RATS AFTER FOURTEEN CONSECUTIVE DAYS OF TREATMENT WITH LSD OR SALINE FOLLOWED BY ONE DAY WITHOUT TREATMENT PRIOR TO SACRIFICE 
Page 28

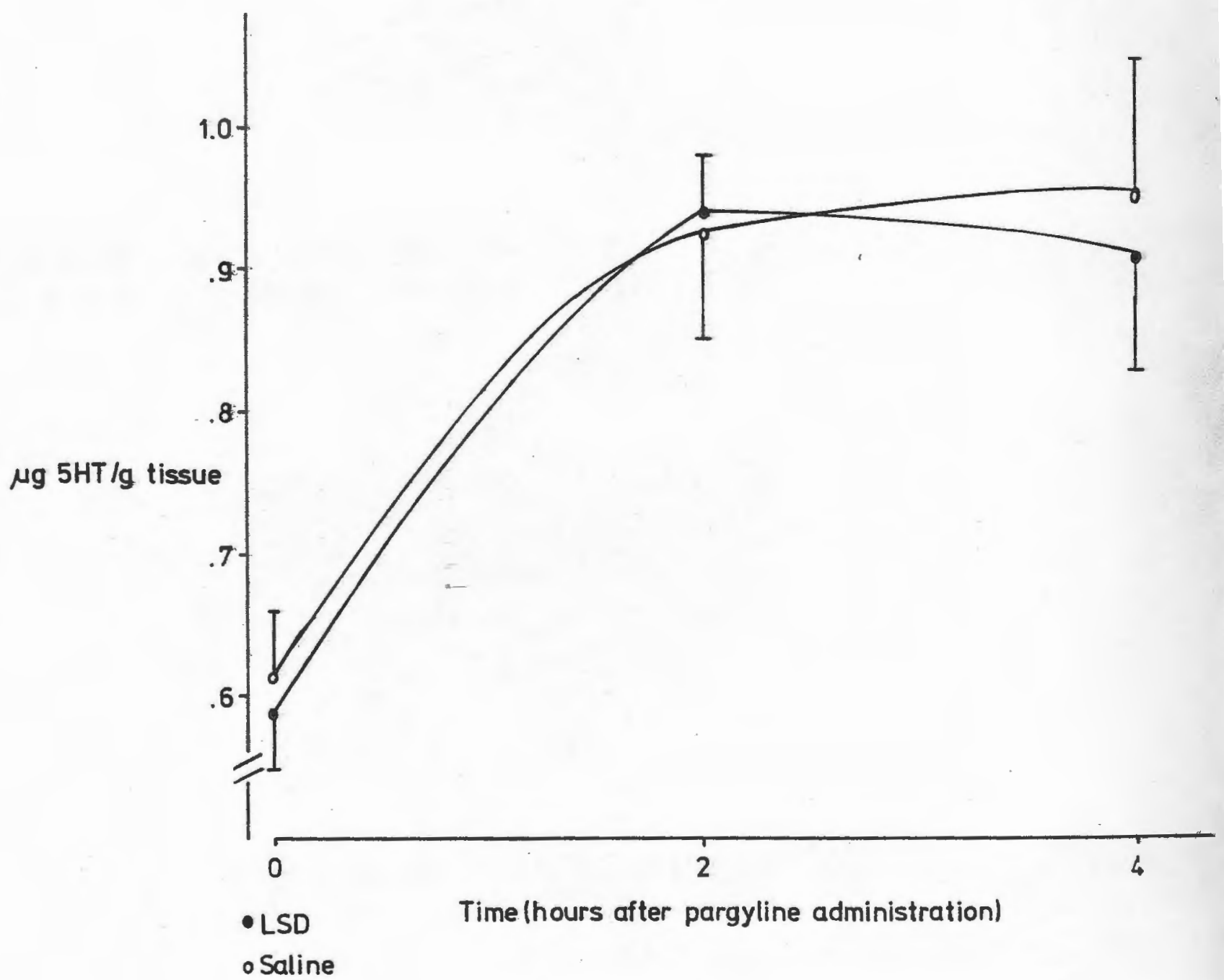


Figure 5. A COMPARISON OF SEROTONIN TURNOYER IN THE CEREBRAL CORTEX OF RATS AFTER FOURTEEN CONSECUTIVE DAYS OF TREATMENT WITH LSD OR SALINE FOLLOWED BY FOURTEEN DAYS WITHOUT TREATMENT PRIOR TO SACRIFICE 
Page 30

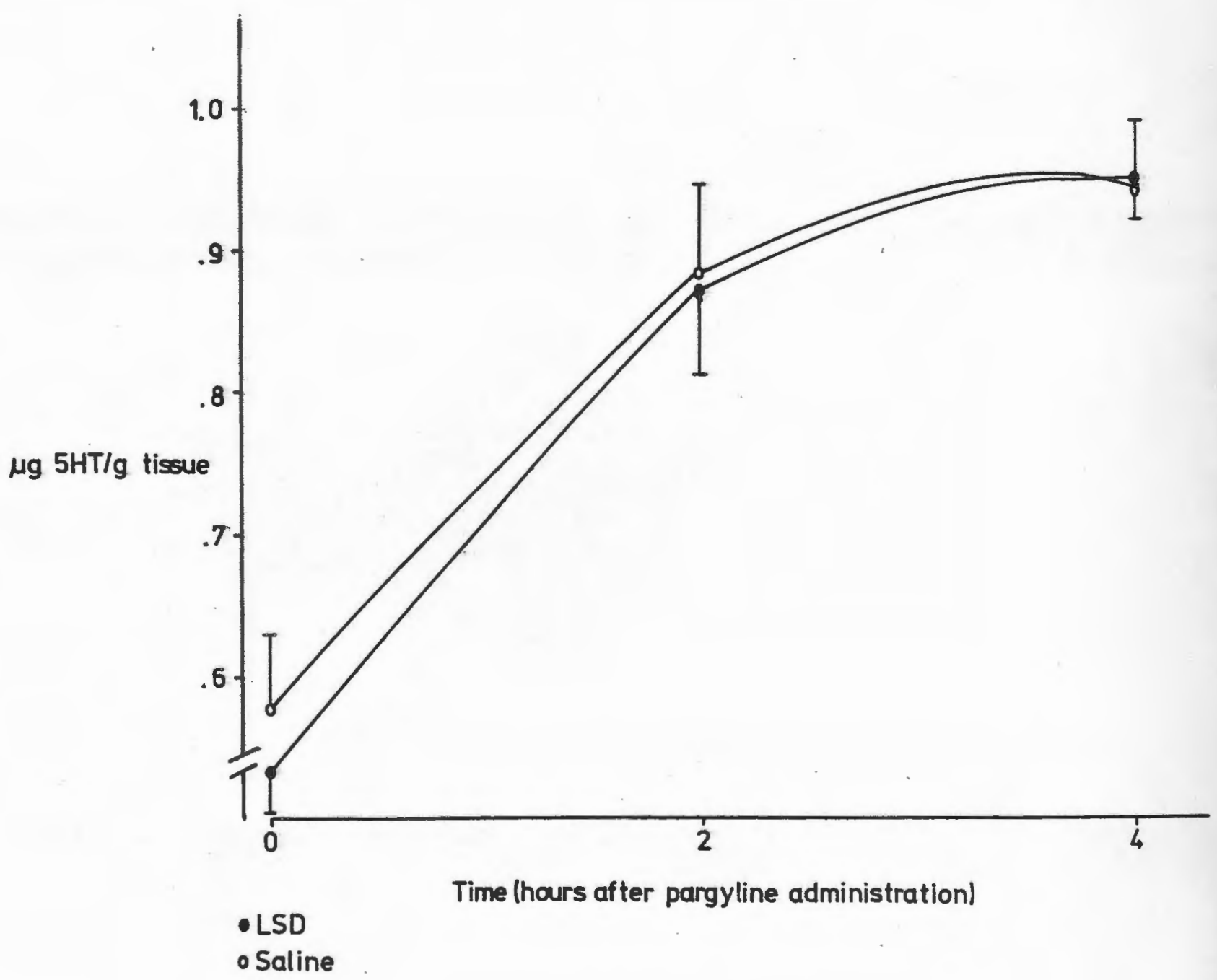


Page 31

Figure 6. REPRESENTATIVE SCATCHARD PLOT ANALYSIS OF THE DATA IN TABLE 3, EXPERIMENT 2 
Page 32

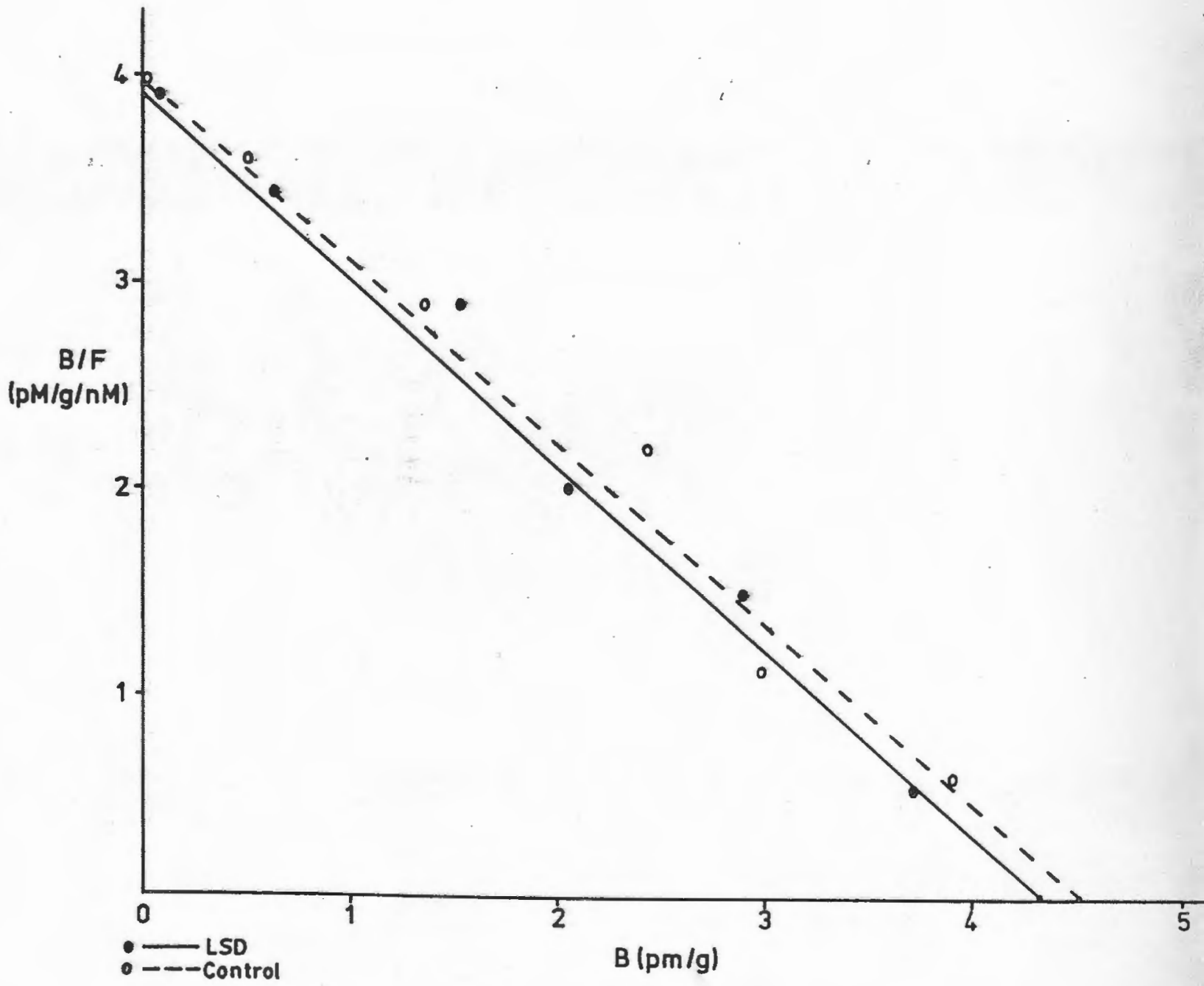


DISCUSSION

This study has addressed the hypothes is that psychotic effects diagnosed as LSD-induced are due to adaptations or alterations of the functioning of 5-HT neurons in the CNS. Acute administration of LSD produces a significant elevation in 5-HT levels accompanied by a complete cessation of turnover (Rosecrans et al, 1967). This pharmacologic effect is assumed to be related to the human LSD experience due, in part, to the information available on the patterns of innervation of 5-HT neurons. Raphe nuclei $B_{7}, B_{8}$, and $B_{9}$ send efferent fibers via the median forebrain bundle to the amygdala, thalamus, hippocampus, and cortex (Dahlstrom et al, 1964). The fibers of these nuclei are present in the cortex samples utilized for this study.

The results of acute and chronic LSD administration on 5-HT turnover suggest that the drug exerts little persistent effect on biochemical parameters which assess function of 5-HT neurons. Chronic administration of even 10 times the acute LSD dose for 14 consecutive days resulted in no significant alteration in levels or turnover of 5-HT after 1 or 14 days without treatment. Acute LSD at $100 \mathrm{ug} / \mathrm{kg}$ (figure 1) caused a cessation of 5-HT turnover. When levels of 5-HT in cerebral cortex were measured six hours after LSD, the treated rats showed no change in 5-HT levels over the four hours after pargyline administration, while the control rats showed the increase in $5-H T$ characteristic of all the studies. This suggests that the levels of $5-H T$ had risen to a ceiling value and leveled off due to end-product inhibition (inhibition of tryptophan-5-hydroxylase by $5-H T)$. 
Although the 5-HT level at the two-hour time point of figure 3 is significantly different from control, this result can be attributed to experimental error. This study was repeated identically with two times the dose as shown in figure 5, and the results in this case showed no difference from control. Overall, the turnover data suggest that the LSD exerts its effects on 5-HT neurons only when it is present in sufficient quantities in the CNS. The possibility of a residual effect on turnover after LSD is eliminated seems, from this data, to be unlikely.

The synaptosomal uptake of $(3 \mathrm{H}) 5-\mathrm{HT}$ was measured after administration of 5,6-dihydroxytryptamine, a specific 5-HT neurotoxin (Baldessarini et al, 1973; Daily et al, 1973; and Baumgarten et al, 1972). The tricyclic antidepressant, desipramine, was administered one hour prior to the 5,6-DHT. Since desipramine is a specific norepinephrine uptake blocker, it has been used to improve the specificity of 5,6-DHT for 5-HT neurons. The 5,6-DHT was injected intracerebrally into the lateral ventricle since it would have been rapidly metabolized and excluded from the CNS if administered parenterally. The 5,6-DHT diminished the uptake of (3H) 5-HT by $29 \%$ (Table 1). Chronic treatment with LSD followed by 1 or 14 days without treatment produced no alteration in uptake of (3H) 5-HT in rat cortex (Table 1). Rats given other drugs; for example, metamphetamine at $25 \mathrm{mg} / \mathrm{kg} /$ day for four days, exhibit impaired uptake of (3H) $5-\mathrm{HT}$ even after 21 drug-free days (Ricaurte et al, 1981).

Receptor binding experiments for both (3H) 5-HT and (3H)-spiroperidol were carried out in order to examine 5-HT receptors according to their currently accepted order. That is that the 5-HT receptor in the rat 
cerebral cortex is made up of two subgroups. One subgroup binds (3H) $5-H T$ and this is displaceable by unlabeled 5-HT with an IC50 of approximately $10^{-7}$ M. (Creese and Snyder, 1978; Peroutka and Snyder, 1979). This suggests a high affinity of this receptor for 5-HT. The other currently accepted 5-HT receptor binds $(3 \mathrm{H})$-spiroperidol and this is not easily displaced by $5-H T$, but is displaceable by $5-H T$ antagonists such as unlabeled spiroperidol, mianserin, or cinanserin (Seeman et al, 1980; Quik et al, 1978).

Receptor binding experiments for both (3H) 5-HT and (3H)-spiroperidol showed no significant changes in $\mathrm{Kd}$ or $\mathrm{Bmax}$ (Tables 2 and 3 ). These two parameters of receptor populations are frequently used to measure and characterize specific neurotransmitter receptors. Other researchers have shown the $\mathrm{Kd}$ and Bmax of brain receptor populations to be adaptable to prolonged exposure to certain drugs. Specifically for the 5-HT receptor, Akiyama et al (1982) showed changes in Bmax of (3H)-spiroperidol binding after 14 days of $4 \mathrm{mg} / \mathrm{kg} /$ day treatment with methamphetamine followed by seven drug-free days. Segawa and Urehara (1981) showed a decrease in (3H) 5-HT specific binding in rat whole brain preparations after four consecutive days of treatment with methiothepin and mianserin, two antidepressant drugs. Leysen et al (1982) showed that mechanically-produced cerebral lesions caused a significant decrease in binding sites for the spiroperidol-sensitive receptor. Research using the discussed methods has yielded knowledge about the dysfunction of the 5-HT system induced by toxic agents. The data generated by Diaz and Huttenan (1972) and Peters $(1973,1976)$ suggest that our experiments with LSD, utilizing the 
described doses (at least 10 times the LSD ED50) and the time periods of treatment employed, would have been suitable for uncovering impairments in the 5-HT system had they occurred.

Assuming a psychosis due to exposure to LSD does exist in humans, the biochemical alterations accompanying it are not measurable given the rat model which we utilized, the treatment conditions employed, and the available methodology. It is the conclusion of this study that no evidence was found to support the hypothesis that LSD produces long-lasting alterations in the functioning of $5-H T$ neurons and that this is the basis for LSD-induced psychosis. 


\section{BIBL IOGRAPHY}

Aghajanian, G. K. and Bing, D. H. L.: Persistence of lysergic acid diethylamide in the plasma of human subjects. Clin. Pharm. Ther. 5: 614,1964 .

Aghajanian, G. K. and Vandermaelen, C. P.: Intracellular recordings from serotonergic dorsal raphe neurons: pacemaker potentials and the effect of LSD. Brain Res. 238-469, 1982.

Aghajanian, G. K., Haigler, H. J. and Bloom, F. E.: LSD and serotonin: direct actions on serotonin neurons in the rat brain. Life Sci. 11: 615,1972 .

Akiyama, K., Sato, M., Kashikara, K. and Otsuki, S.: Lasting changes in high-affinity $3 \mathrm{H}-\mathrm{sp}$ iperone binding to the rat striatum and mesolimbic area after chronic methamphetamine administration: evaluation of dopaminergic and serotonergic receptor components. Biol. Psychiat. 17: 1389-1409, 1982.

Baldessarini, R. J.: Biogenic amine hypothesis in affective disorders. In The Nature and Treatment of Depression, Flachi, F.F. and Gerson, S.C., (eds.), Wiley and Sons, Inc., New York, 1975, pp 347-385.

Baldessarini, R. J. and Gerson, S.: Effects of 5,6-dihydroxytryptamine on the metabolism of 5-hydroxytryptamine in the central nervous system of the rat. J. Pharm. Pharmac: 25: 647-648, 1973.

Baumann, P. A. and Waldmeier, P. C.: Further evidence for negative feedback control of serotonin release in the central nervous system, Naunyn-Schmiedeberg's Arch. Pharmacol, 317: 3643, 1981, 
Baumgarten, H. G., Evetts, K. D., Holman, R. B., Iversen, L. L., Vogt, M. and Wilson, G.: Effects of 5,6-dihydroxytryptamine on monaminergic neurons in the central nervous system of the rat. J. Neurochem. 19: 1587-1597, 1972.

Bennett, J. P. and Snyder, S. H.: Serotonin and 1ysergic acid diethylamide binding in rat brain membranes: relationship to postsynaptic serotonin receptors. Mol. Pharm. 12: 373-389 (F175).

Blackshear, M., Steranka, L. and Sander-Bush, E.: Multiple serotonin receptors: regional distribution and effect of raphe lesions. Eur. J. Pharm, 76: 325-337, 1981.

Bogdanski, D. F., Tissari, A. and Brodie, B. B.: Role of sodium, potassium, ouabain and reserpine in uptake, storage and metabolism of biogenic amines in synaptosomes. Life Sci: 17: 419-428, 1968.

Chandler, A. L. and Hartman, H. A.: Lysergic acid diethylamide (LSD-25) as a facilitating agent in psychotherapy. Arch. Gen. Psychiat: 2 : 286-299, 1960 .

Ciarlone, A. E.: Modification of a spectrophotofluorometric method of analyzing serotonin, norepinephrine, and dopamine in one brain sample. Microchem. J. 21: 349-354.

Cohen, S.: Lysergic acid diethylamide: side effects and complications. J. Nerve Met. Dis. 130: $30-40,1960$.

Cohen, S. and Ditman, K. S.: Complications associated with lysergic acid diethylamide (LSD-25). J. Am. Med. Assn. 181: 161-162, 1962.

Creese, 1. and Snyder, S. H.: Spiroperidol labels serotonin receptors in rat cerebral cortex and hippocampus. Eur, J. Pharmacol, 49: 201-202, 1978. 
Curzon, G. and Green, A. R.: Rapid method for the determination of 5hydroxytryptamine and 5-hydroxyindolacetic acid in small regions of the brain. Brit. J. Pharmacol: 59: 653-655, 1970.

Dahlstrom, A. and Fuxe, K.: Evidence for the existence of monoamine containing neurons in the central nervous system. 1. Demonstration of monoamines in cell bodies of brain stem neurons. Acta Physiol. Scand. $62(232): 1-55,1964$.

Daly, J., Fuxe, K. and Jonsson, G.: Effects of intracerebral injections of 5,6-dihydroxytryptamine on centeràl monamine neurons: evidence for selective degeneration of central 5-hydroxytryptamine neurons. Brain Res: $49: 476-482,1973$.

Diagnostic and Statistical Manual of Mental Disorders, Third edition, Washington, D.C., APA, 1980, pp 1.55-156.

Diaz, J. L. and Huttenan, M. O.: Persistent increase in brain serotonin turnover after chronic administration of LSD in the rat. Science 174: $62-64,1972$.

Elkes, J.: The dysleptics: note on a no man's land, Compar. Psychiat. 4. $195-198,1963$.

Erdo, S. L., Kiss, B. and Rosdy, B.: Effect of salbutamol on the cerebral levels, uptake and turnover of serotonin. Eur. J. Pharm: 78: $357-361,1982$.

Fillion, G., Fillion, M., Spirakis, C., Bahers, J. and Jacob, J.: 5-Hydroxytryptamine binding to synaptic membranes from rat brain. Life Sci. 18: 65-74, 1975. 
Fillion, G., Rousselle, J., Fillion, M., Beaudoin, D., Goiny, M., Deniau, J. and Jacob, J.: High-affinity binding of (3H) 5-hydroxytryptamine to brain synaptosomal membranes: comparison of $(3 \mathrm{H})-$ lysergic acid diethylamide binding. Mol. Pharmacol: 14: 50-59, 1977.

Fink, M., Simeon, J., Hawe, W. and $\mid t i 1, T_{\text {.: }}$ Prolonged adverse reactions to LSD in psychotic subjects. Arch. Gen. Psychiat. 15: 450$454,1966$.

Frosch, W. A., Robbins, E. S. and Stern, M.: Untoward reactions to lysertic acid diethylamide (LSD) resulting in hospitalization. New Eng. J. Med. 273: 1235-1239, 1965.

Garver, D. L., Davis, J, M. and Minervien, J.: Biogenic amine hypothesis of affective disorders. Life Sci $24: 383-394,1979$.

Glowinski, J. and Iversen, L. L.: Regional studies of catecholamines in the rat brain. 1. The disposition of (3H)-norepinephrine, (3H)dopamine and (3H)-dopa in various regions of the rat brain. J. Neurochem. 13: 655-670, 1966.

Gray, E. G. and Whittaker, V.: P.: The isolation of nerve endings from brain: an electron microscopic study of cell fragments derived by homogenization and centrifugation. J. Anat. 96:79-87, 1962.

Horowitz, M. J.: Flashbacks: recurrent intrusive images after the use of LSD. Am. J. Psychiat: 126: 565-569, 1969.

Kellar, K. T., Cascio, C. S., Butler, J. A, and Kurtzke, R. N.: Differential effects of ECS and antidepressant drugs on serotonin-2 receptors in rat brain. Eur. J. Pharm, 69: 515-518, 1981. 
Kuhar, M. J.: Neurotransmitter uptake: a tool in identifying neurotransmitter-specific pathways. Life Sci. 13: 1623-1634, 1973.

Kuhar, M. J., Roth, R. H. and Aghajamian, G. K.: Synaptosomes from forebrains of rats with midbrain raphe lesions: selective reduction of serotonin uptake. J.P.E.T: 181: 36-45, 1972.

Levine, J. and Ludwig, A. M.: The LSD controversy. Compar. Psychiat. 5: $314-321,1964$.

Leysen, J. E. and Laduron, P. M.: A serotonergic component of neuroleptic receptors. Arch. Int. Pharmacodyn; 230: 337-339, 1977.

Leysen, J. E., Geerts, R., Gommeren, W., Verwimp, M. and Van Gompel, P.: Regional distribution of serotonin-2 receptor binding 5 ites in the brain and effects of neuronal lesions. Arch. Int. Pharmacodyn. 256: $301-305,1982$.

Ling, T. M. and Buckman, J.: The use of lysergic acid in individual psychotherapy. Proc, Roy. Soc. Med: $53: 45,1960$.

Lowry, O. H., Rosebrough, N. J., Farr, A. L. and Randall, R, J,: Protein measurement with the Folin phenol reagent, J, Biol. Chem. 193: $265-275,1951$,

Maggin, A., U'Prichard, D. and Enna, S.: Differential effects of antidepressant treatment of brain monoaminergic receptors. Eur. J. Pharm. $61:$ : 91-98, 1981.

Middlemiss, D. N., Carroll, J. A., Fisher R, W, and Mounsey, I, J.: Does $(3 \mathrm{H})$-spiroperidol label a $5-H T$ receptor in the frontal cortex of the rat? Eur. J, Pharmacol, 66: 253-254, 1980. 
Millard, S.. A., Costa, E. and Gal, E. M.: On the control of brain serotonin turnover rate by end-product inhibition. Brain Res, 40 : $545-551,1972$.

Miller, F. P., Cox, R. H., Snodgrass, W. R, and Maickel, R, P.: Comparative effects of p-chlorophenylalanine, p-chloroamphetamine, and pchloro-N-methylamphetamine on rat brain norepinephrine, serotonin, and 5-hydroxyindole-3-acetic acid, Biochem. Pharm: 19: 435-442, 1969.

Neff, N. H. and Tozer, T. H, " In vivo measurement of brain serotonin turnover rate by end product inhibition. Adv; Pharmacol: 6. 97$109,1968$.

Neff; N. H., Lin, R. C., Ngai, S, H, and Costa, E.: Turnover rate measurements of brain serotonin in unanesthetized rats. Adv. Biochem, Psychopharm: 1: 91-109, 1969,

Noble, E. P., Surtman, R. J. and Axelrod, J.: A simple and rapid.method for injecting $(3 \mathrm{H})$-norepinephrine into the lateral ventricle of the rat brain. Life Sci: 6: 281-291, 1967 .

Peroutka, S. J. and Snyder, S. H,: Multiple serotonin receptors: differential binding of (3H)5-hydroxytryptamine, $(3 \mathrm{H})$-lysergic acid diethylamide, and (3H)-spîroperidol. Mol. Pharmacol : 16: 687-699, 1979 .

Peroutka, S. J. and Snyder, S. H.: Two distinct serotonin receptors: regional variations in receptor binding in mammalian brain. Brain Res. 208: $339-347,1981$. 
Peroutka, S. J., Lebovitz, R. M. and Snyder,. S. H.: Serotonin receptor binding sites affected differentially by guanine nucleotides. Mol. Pharm. 16: 700-708, 1979.

Peters, D. A. V.: Chronic lysergic acid diethylamide administration and serotonin turnover in various regions of rat Brain. J. Neurochem. 23: $625-628,1974$.

Peters, D. A. V.: Comparison of the chronic and acute effects of dIysergic acid diethylamide (LSO) treatment on rat brain serotonin and norepinephrine. Biochem...Pharm: 23: 231-237, 1973.

Peters, D. A, V.: Persistent effects of repeated injections of d-lysergic acid diethylamide on rat brain 5-hydroxytryptamine and 5-hydroxyindolacetic acid levels. Biochem. Pharm, 26: 1085-1086, 1976.

Quik,.M., Iversen, L. L., Larder, A. and Mackay, A. V. P.: Use of ADTN to define specific (3H)-spiperone binding to receptors in brain. Nature $274: 513-514,1978$.

Ricaurte, G. A, Schuster, C, R, and Seiden, L. S,: Long term effects of repeated methylamphetamine administration on dopamine and serotonin neurons in the rat brain: a regional study. Brain Res: 193; $153-163,1980$.

Rosecrans, J. A., Lovel 1, R. A. and Freedman; D. X.: Effects of lysergic acid diethylamide on the metabol ism of brain 5-hydroxytryptamine. Biochem. Pharm, 16: 2011-2021, 1967.

Rosenthal, S. H,: Persistent hallucinosis following repeated administration of hallucinogenic drugs. Am, J. Psychiat: 121: 238-244, 1964. 
Sankar, D. V. S.: LSD--A Total Study, P. J. D. Publications, Ltd., Westbury, New York, 1975.

Seeman, P., Westman, K., Coscina, D. and Warsh, J. J.: Serotonin receptors in hippocampus and frontal cortex. Eur. J. Pharmacol. 66: $179-191,1980$

Segawa, T., Mizuta, T. and Nomura, Y.: Modifications of central 5-hydroxytryptamine binding sites in synaptic membranes from rat brain after long-term administration of tricyclic antidepressants. Eur. J. Pharmacol: 58: $75-83,1979$.

Segawa, T. and Uehara, M.: Effect of methiothepin on imipramine or mianserin induced subsensitivity of serotonergic receptors. Life Sci: $30: 809-812,1981$.

Shaskan, E. G. and Snyder, S. H.: Kinetics of serotonin accumulation into slices from rat brain: relationship to catecholamine uptake. J.P.E.T: $175: 404-418,1970$.

Tozer, T. N., Neff, N. H, and Brodie, B, B.: Application of steady state kinetics to the synthesis rate and turnover time of serotonin in the brains of normal and reserpine treated rats. J.P.E.T: 153: $177-182,1966$

Ungerleider, J. T., Fisher, D. D, and Fuller, M,: The dangers of LSD. J. Am. Med. Assn: 197: 389-392, 1966. Welpton, D.F.: Psychodynamics of chronic lysergic acid diethylamide use. J. Nerv. Ment. Dis: 147: 377-385, 1968. 